\title{
ARQUIVOS
}

\section{O REGISTRO HISTÓRICO DO EXÉRCITO}

O levantamento do histórico do Exército, ou de qualquer de suas Unidades (Corpos de Tropa, Repartições, Estabelecimentos, Escolas, etc), conta sempre com grande facilidade devido à existência dos livros de registros, dos arquivos, e principalmente do Boletim Diário, onde todos os fatos de importância, tais como ordens do comandante e as dos comandos superiores, ocorrências, organizaçāo, efetivos, movimentaçāo de pessoal, deslocamentos, etc., sāo publicados ou transcritos.

Nessas condições, as Unidades do Exército mantém em seus arquivos nāo só os próprios documentos, mas também os oriundos dos escalóes superiores, inclusive os Boletins. Pode-se dizer que tôda Unidade do Exército, desde que seja daquelas considerada tradicional (ou detentora do arquivo de qualquer delas), há de ter sob sua guarda documentos importantes. Pode-se exemplificar com as Unidades que integraram a Fôrça Expedicionária Brasileira, que conservam em seus arquivos tôda a documentação referente à Campanha. Algumas das Unidades revolucionárias de 1932 não tiveram seus arquivos destruidos após a derrota, o que aconteceu com a maioria delas, e ainda conservam alguns documentos dêsse periodo. Também sāo freqüentes as coleções completas dos Boletins do Exército, desde antes de terem êsse nome, ou o de "Bóletim do Departamento da Guerra", quando eram as "Ordens do Dia do Quartel General do Exército na Côrte". Começaram estas a ser impressas em 18 de fevereiro de 1857, quando Ministro da Guerra o entāo Marquês de Caxias. Abrangem, portanto, todo o período da Guerra do Paraguai.

Nem todos os documentos, porém, sāo conservados nas Unidades. Certos documentos, que nāo mais necessitam ser consuítados, devem ser recolhidos ao Arquivo do Exército, cuja Diretoria tem, entre as suas obrigações, a de "organizar memoriais e fazer reconstituições históricas".

Semelhantemente, o levantamento biográfico é fácil de ser 
feico, pois se mantém em dia para todos os militares, as "relações de alterações" ou assentamentos. Para os oficiais, por exemplo, sāo tiradạs cópias semestrais, das quais, além da que fica arquivada no Corpo de origem, uma é entregue ao interessado e outra é remetida ao Ministério da Guerra. Estabelecem ainda as "Instruções para Escrituração do Histórico da Vida dos Oficiais" que as folhas de alterações dos oficiais generais sirvam de base à biografia dos Generais do Exército Brasileiro, a ser levantada pela Secretaria Geral do Ministério da Guerra.

Tais circunstâncias têm permitido sejam publicados inúmeros livros, quer de História do Exército, quer de biografias dos chefes. Assim, um exemplo é o volume "O EXÉRCITO BRASILEIRO", publicado em 1939 pela Diretoria do Arquivo do Exército, e organizado pelo cel. T. Faustino da Silva, onde se estuda a organizaçä́o e as paradas (sedes) dos Corpos de Tropas, desde os tempos coloniais até 1934 .

Quanto às biografias dos chefes, a existência das "fés-de-ofício" permitiu que se organizasse um trabalho mais alentado que o anterior. Trata-se dos três volumes, editados pela "Biblioteca Militar" e denominados "Os GENERAIS DO EXÉRCITO BRASILEIRO". Os dois primeiros sairam em 1940, como reediçāo de um trabalho do cap. A. P. Maciel da Silva, publicado inicialmente em 1907. O terceiro volume veiu à luz em 1942, da autoria de Laurêncio Lago, e abrange o período de 1860 a 1889 , enquanto a obra tôda abrange o período do Império.

Com os exemplos acima procurou-se mostrar o valor que têm os arquivos do Exército, mesmo na sua organizaçāo do século passado. $O$ que se deseja apresentar, contudo é um ainda recente aviso ministerial estabelecendo instruções pormenorizadas para o registro histórico das Unidades (Aviso n.o 804, de 16 de dezembro de 1950, publicado no Diário Oficial de 18 do mesmo mês). Nāo se trata de nenhuma inovaçāo para o Exército, como já se féz entender desde o início. Aliás, em 1919 sairam umas "Instruções paia a organizaçāo e redaçäo do Histórico dos Corpos e Grandes Unidades em Campanha e em Manobras", e, por, outro lado, é disposição regulamentar vigente a escrituração de um Livro de Registro Histórico nas Unidades. Desta forma, a ordem ministeriai acima referida veiu completar, sistematizar e controlar disposições anteriores, além de regular sua execuçāo. As instruções baixadas $s \geq$ destinam a "coordenar a coleta de elementos, dados e informaçóes essenciais destinados à História completa e fidedigna do Exército Brasileiro e à formaçāo de tradições militares e à manutençã̃o do "espírito do corpo."

Assim, depois de estabəlecer os considerandos iniciais:

"Considerando que a história militar, além de proporcionar 
conhecimentos básicos para o estudo da ciência da guerra, ainda constitui fonte inesgotável de nobres tradições militares e de sadio "espírito de corpo", umas e outros tão necessários à existência ¿ ao prestígio das fôrças armadas;"

"Considerando que brilhantes feitos militares e ações individuais de belo valor moral muitas vêzes se perdem, pela deficiência do registro ou pela falta de divulgação oportuna e merecida;",

"Considerando que, para evitar o olvido ou a deformaçāo da rerdade histórica, é imprescindivel cuidar do registro oportuno e correto dos fatos e acontecimentos que interessem ao Exército;" as instruções determinam quatro espécies de documentos: o Registro Histórico, o Diário de Manobras, o Diário de Campanha e o Relatório de Campanha, sındo os dois últimos exclusivos do tempo de guerra.

O Registro Hiśótico conterá informações e notícias sôbre a organizaçāo e vida das Unidades, de modo a permitir a redaçāo fiel e objetiva da História do Exército Brásileiro. O Diário de Manobras registrará os trabalhos e exercícios realizados em manobras de Grandes Unidades. O Diátio de Campanha se fará durante as operaçôes de querra e periodos revolucionários e conterá a descrição das operações militaras, bem como os ensinamentos colhidos. Finalmente, o Relalótio de Campanha registrará as informações de caráter administrativo e logistico da campanha.

As "Instruçōes" estabelecem ainda pormenores de execuçāo e determinam o repertório dos assuntos a serem registrados e as fontes que devem ser consideradas, tais como Boletins Internos, Relatórios, Ordens de serviço, Partes de Combate, Ordens Gerais de Operações, etc. Uma cópia de cada um dêsses documentos será enviada semestralmente ao Estado Maior do Exército, que nāo só controlará a sua execuçז̃:o, como ficará habilitado a publicar "trabalhos históricos de interêsse profissional, e propiciar a publicaçāo de memórias históricas ou monograficas sôbre a História completa das Unidades, Repartições ou Estabelecimentos".

A preocupaçāo dos chefes militares em estabelecer o "Registrn Histórico" é um exemplo que deve ser imitado. De fato, apesar de o Exército dispor de maior número de registros burocráticos que qualquer organizaçāo, ainda é feito o "Registro Histórico", de maneira homogênea e centralizada, o que, em qualquer tempo (desde já, pois as Instruções pediram um resumo histórico a partir da criaçāo da Unidade) possibilitará quaisquer pesquisas que tenham de ser feitas, com o mínimo de busca aos arquivos gerais, que se reservarāo aos trabalhos especializados.

Sem dúvida, muitas organizações já seguem procedimento semelhante. Mas, se o exemplo puder ser seguido por tôdas as instituições que tenham o menor papel nas atividades públicas atuais 
(escolas, repartições públicas, entidades autárquicas, organizações religiosas ou beneficientes, indústrias, etc., etc.,) muito se teria feito, facilitando aos pesquisadores futuros os elementos que procurarāo para estudar e interpretar os fatos dos tempos presentes.

Cap. WALTER JOSE' FAUSTINI 